\title{
PECULIARITIES OF DISCUSSING TAX DISPUTES IN COURT
}

https://doi.org/10.47743/jopafl-2021-19-12

\author{
Marine KORDZADZE \\ Grigol Robakidze University
}

\begin{abstract}
Discussions of tax disputes in courts are characterized by certain peculiarities. These discussions gain special significance because these have implications for the economic stability of the country and the rights of the citizens. After all, unlike the disputes over other laws and regulations introduced by the government that affect an individual only in specific aspects, tax liabilities, being financial in nature, influence all the activities of a person throughout their lives because taxing the income of a person is a substantial and carefully designed mechanism of the state that interferes in a person's activities. In view of the foregoing, this part of the article deals with the peculiarities of discussing tax disputes in court, its existing practice, the experience of other countries, and on that basis, analyses the existing problems of legislative regulation of tax disputes and ensuring their finalization to draw certain conclusions.
\end{abstract}

Keywords: Tax law, tax dispute, legislative

\section{Introduction}

While the state has the legal right to impose and collect taxes to mobilise funds to meet its budgeted expenditure, physical and legal entities are bound to the duty of paying the taxes. Adam Smith and other economic thinkers of the middle-ages have described the importance of taxes and noted that, while imposing taxes, states should be guided by the principles of universality, definiteness, selecting the objects of taxation, and justice (Gorbunova, 1996; Financial Law, Moscow, p.17). Historical experience shows that the issues related to taxes are distinguished by complexity and variety in the modern legislative space. Taxes never lose their actuality and are becoming more and more significant. The famous phrase of one of the authors of the Declaration Of Independence of the United States, Benjamin Franklin - "In this world, nothing can be said to be certain, except death and taxes" still holds (http://en.wikiquote.org/wiki/Benjamin_Franklinix. [24.09.2012]). A well-thought-out and well-administered tax legislation is the most significant source of support for business and economic development. Concessionary tax legislation serves as the most significant factor for foreign investors and development of their projects.

The slogan 'Pay Your Taxes to Sleep Well’ always justifies itself in practice. There are frequently reported cases of taxpayer and the tax body's disagreements over the amount and the method of computation of tax and gives the tax-payers sleepless nights. What confounds the complexity in the disputes is that the taxpayer is the weak party and, in most cases, unable to defend itself against the tax body, which is a subordinate body of the state. A two-stage system of dispute review is operated by the Ministry of Finance. Revenue service is the first stage at which the tax-payer must initially appeal against the decision of the revenue service itself. If their appeal is not accepted at the first stage, the taxpayer can take the case to the second stage - the dispute resolution board at the Ministry of Finance. The law-courts serve as an alternative mechanism of dispute resolution. Independent of the revenue service and the dispute board at the ministry of finance of Georgia, the taxpayer 
can appeal directly to the court. However, experience shows that the taxpayer prefers to resolve the dispute through the revenue service at the initial stage.

Even though the mechanism of discussing revenue service disputes is frequently referred to, the system of dispute review is continuously being reformed through the EUfunded project, which applies to the reform of the system of disputes and its possible changes. Minimising the flexibility of interpretation of the tax norms is the cornerstone of these reforms. Lack of clarity in the norms set out in the tax code and their ambiguous interpretation has been the problem published definitions of the tax code (Kemularia 2014, System of Tax Disputes of Georgia, articles/business and economy).

\section{Structure of Bodies Exercising Justice over Tax Disputes in Georgia}

Georgia, and many other states, grant persons the constitutional right to approach a court of law to protect personal rights and freedoms. According to existing legislation, the authority of the court is independent of other branches of state and common courts dispense justice through civil, administrative and criminal law procedure. The tiers in the judicial system are the city (regional) courts, the appellate courts and the Supreme Court. The city (regional) court is the court of the first instance that examines the cases brought before it privately for judgement. The appellate court is the court of the second instance in which a bench of three judges, in a collegiate manner, considers the appeals against the decisions of the regional (city) courts. The Supreme Court of Georgia is the highest court and the final instance as a court of justice with jurisdiction over the whole territory of Georgia. It supervises, through the procedural form, the implementation of justice in common courts of Georgia. The decision of the Supreme Court of Georgia is final and not subject to further appeal. It is essential to mention while discussing the case in common courts that the legislative acts that regulate the functioning of courts and implementation of justice in the country guarantee the independence of the judges. To be more specific, according to the organic law of Georgia, the judge is independent to decide any case, assesses actual circumstances and decide in accordance with only the Constitution of Georgia, universally recognized principles and norms of international law, others laws, and relying on one's internal belief.

\section{Discussing Tax Disputes in Common Courts}

Tax disputes belong to the category of administrative cases and they are discussed in common courts according to the rules defined by the administrative procedural legislation of Georgia. Though in terms of the general principle of the administrative procedure, the court will not accept a suit against an administrative body, if the plaintiff did not use the right to submit a one-off administrative suit, parts one and three of Article 296 of the Tax Code allow the taxpayer to sue against the decision made under the tax legislation (administrative act) following the system of Ministry of Finance of Georgia or apply directly to the court at any stage of the tax dispute (Tax Code of Georgia, 2018, Tbilisi). The taxpayer appeals against the actions of the tax body before the city (regional) court at the place of their residence by submitting the suit application. The court procedure differs from the discussion of the tax dispute in the system of the Ministry of finance in that the taxpayer is obliged to pay the state customs duty at the following rates, for filing 
the suit application before a city (regional) court $-3 \%$ of the amount in dispute, but not less than 100 laris and not more than 3000 laris in case of a physical entity or 5000 laris in case of a legal entity; in case of appellate complaint (appellate court), $4 \%$ of the amount in dispute but not less than 150 laris and not more than 5000 laris in the case of a physical person or 7000 laris in case of a legal entity; in respect with the cessation appeal (Supreme Court) $-5 \%$ of the amount in dispute but not less than 300 laris and not exceeding 6000 laris in case of a physical entity, or 8000 laris in case of the legal entity.

The taxpayer must submit the suit application in a tax dispute to the court within 20 days from the date of the decision of the Ministry of Finance. If the taxpayer chooses to submit the tax dispute directly to a court, the time allowed is 30 days from the administrative action against the taxpayer. Special rules are set by the administrative procedural code of Georgia for discussing tax disputes. To be more specific, (1) The tax legislation of Georgia lays down that the dispute must be decided within two months from the receipt of the suit application at the court of the first instance. If the case involves some special difficulty, this term may be extended but not more than by two months, which may be granted by a reviewing court. (2) The court of appeals judging the dispute on the points of tax legislation must give the decision in a period not exceeding two months from the date of the appeal.

However, as a rule, the discussion over tax disputes in the court last longer than two months because deciding such cases often requires special knowledge (for example, for understanding the accounting system of the taxpayer in the context of compliance with international accounting standards and/or of international financial reporting, and analyzing the taxpayer's cards and other forms of reporting, etc.). This necessitates inviting specialists and seeking additional details related to the dispute from the plaintiff or the defendant. The decision is made by the court based on the discussion of the case may be appealed against in the Supreme Court. The decision of the city (regional) court may be appealed against in the appellate court by a party to the dispute within 14 calendar days after the receipt of the decision. For appealing against the ruling of the appellate court at the Supreme Court, a period of one month since the receipt of the decision is allowed. The Supreme Court is the final instance of justice in Georgia and its decision is not subject to any further appeal.

While reviewing the tax dispute, and the disputes in other categories, the main function of a court is to make a just and legal decision by studying the factual circumstances and examining the definitions in and the interpretation of tax legislation (including, vague and obscure ones). In many cases, the court, as the body of justice, carries out such extension of the regulation commensurate to legislation, which serves as the just means of achieving the logical aim. A statistical analysis of the tax disputes in court and their results reveal that because the number of such disputes in this administrative category that reaches the courts is relatively small. Therefore, courts have fewer opportunities to accumulate experience in deciding the disputes of this specific nature. This lack of experience and practice eventually affects the quality of decisions. In 2017, the chamber of administrative affairs of the Supreme Court discussed around 80 cessation appeals related to the tax disputes. Of these, about $40 \%$ were decided in favour of administrative bodies and $60 \%$ were decided in favour of legal and physical entities. It is worth mentioning that none of the disputes ended through a settlement (Timer.ge, 9 January 2018. http://www.supremecourt.ge/statistics/). 
Due to the lack of a large enough number of tax disputes in the administrative category there is little possibility of judges developing a special knowledge of tax legislation. This contributes further to the extension of the terms of tax dispute review and the decisions in many cases appear to lack justification. In Georgia, significant importance is attached to the quality and substantiation of the decision given by the court, including in the cases of tax dispute reviews. Because, though the tax is binding only on the parties to the issue, in practice the courts' decisions form precedents to be relied on in deciding future cases. This is so because the courts cannot choose to take a different approach in other similar cases to give decisions that contradict the precedent. Also, as a rule, the judge refers to the previous decisions made by the court on similar or same issues. Therefore, the larger the number of cases the court decides, the larger is the number of precedents to which importance is attached. The importance of the precedents set by the Supreme Court is great for both judicial bodies and administrative bodies because the principles and approaches introduced by these decisions necessitate changes in tax legislation.

In practice, the court is the only body authorised to define and generalise while discussing the case, the norm of the law and/or any normative act, study its logic and interpret these to clear the obscurity and confusion surrounding the norm to define the proper way of applying the legal norms. The court is obliged to discuss the constitutionality of this or that particular norm and if it concludes that, in the context of a specific case, there is sufficient ground to fully or partially regard the norm to be fully or partially incommensurate with the Constitution of Georgia, it has to stop proceeding with the case and hand the issue of the constitutionality of the norm to the Constitutional Court of Georgia for further review. Therefore, in light of the foregoing, it is possible to say that the function of the court in practice is not only to implement justice but also to logically and in a just manner clarify the obscure and confusing norms of legislative and legal normative acts to ensure the balance of rights between the administrative bodies and private persons. According to USAID, tax dispute discussions have positive and negative sides in Georgia (Efficient institutions of tax dispute resolution, 20 February 2012.).

Positive sides:

-Independent court discusses the tax dispute, which significantly increases the quality of paying the tax objectively and without extending the actual term.

Parties to the court process have much more legislative levers to justify their side (for example, getting opinions of experts or specialists, such acts as selling of taxpayers' property, etc., inviting witnesses and carrying out examination.

Negative sides:

-Due to the long discussions of tax disputes in courts, the taxpayer frequently faces financial difficulties. In other cases, the long time needed for review, persons refuse to appeal to the courts, whether or not the person thinks the amount charged is right, pays the tax or tries to sign a tax agreement.

\section{Peculiarities of suit applications related with the tax dispute}

The suit, in general, is the procedural means of raising a dispute for protecting rights from violation. All persons who wish to protect their rights legal means can use this procedure. The right to file the suit enables one to apply to a court to protect one's personal interests. This right extends to all eligible physical and legal entities. To put the right into 
practice, it is necessary to follow the rule defined by the civil procedural legislation (Liluashvili T., 1999; Civil Cases Record-Keeping in Court, Tbilisi, pp. 25-26). The case is filed at the court of the first instance based on the administrative suit. The case should be in a written form and meet the requirements of the civil procedural code. In case of a tax dispute, the requirement for filing a suit may be as follows considering all administrative acts: tax request request-order issued by the administrative body, order to tax accrual, any orders issued by the revenue service and Ministry of Finance. Abolition or correction of the act of control. It needs to be stated that according to present practices, the act of control is not an administrative act since the tax code defines that it is subject to appeal and list similar decisions made by the revenue service or the Ministry of Finance and annulled by the courts after the process of discussing the dispute. Violation of procedural clauses may also serve as the subject of dispute.

Tax disputes are discussed by the courts of Georgia are over issues of tax control, the rule of administering the customs duties, control of financial-economic activities, questioning the legitimacy of tax acts in the section that imposes profit tax, payment of VAT, filling of the tax return, obligation to file the tax return, VAT credit, defining the time of being registered as the VAT payer, imposing the obligation over the provider of goods for VAT payment and filling in the tax invoice, the tax request, the rule about submitting the tax notification to the individual entrepreneur, basis for raising the tax request while registering presumptive tax, questioning the liegitimacy of the tax request, obsolescence of the tax request, tax mortgage, obsolescence of the tax mortgage right, tax law violation, fine for not meeting the terms of submission of the tax return and carrying out activities without being registered as the VAT payer, pre-conditions for weighbill, requesting the extension of the term for submitting property and profit tax declarations, transportation of goods for economic activity without the weighbill, to assert the fact of not registering goods sold during the simplified rules of registering the expenditure, amount of good revealed without the delivery note, and to be recognizing as pseudo-persons. Administrative suit and administrative judicial procedure are discussed in the court of the first instance in terms of the administrative procedural code and the civil procedural code. All aspects and peculiarities of discussing administrative legislative disputes are reflected in the administrative procedural code. First of all, it defines the procedure to be followed by the court to examine the evidence while settling disputes, which introduces the basics of inquisition in administrative law. The administrative procedural code reflects the principle of balancing private and public interests interwoven into the norms of the general administrative code. Eventually, it can be stated that the main stipulations of modern European administrative judicial procedures are, more or less, fully demonstrated in the administrative procedural code of Georgia.

\section{Procedure of tax dispute discussion by the tax courts of foreign countries and the tax tribunal}

With the view to analyse the basics that define the efficiency of tax dispute settlement in tax courts and tribunals, it is important to discuss not only the structure of tax courts and the procedures of dispute review in the laws of countries of continental Europe and those of the law of precedents law but also peculiarities of functioning of the tax 
tribunal and circumstances defining its efficiency. With this purpose, the following examples from several countries are discussed:

\section{The United States of America}

The aim of discussing the structure of the tax courts of the USA and the rules that govern their functioning is to study the functioning of the mentioned structures in the countries where the law of the precedent is followed and its essence.

\section{Denmark}

While studying the system of the tax courts, it is essential to analyse not only the possibility of discussing the tax disputes in the court system but also the efficiency of the tax tribunal and its positive and negative sides.

\section{Federal Republic of Germany}

Germany is one of the founder countries of the European continental law. Its legislation has been an example for numerous countries. While studying the process of discussion of disputes in specialized courts, a review of the examples of fiscal courts of mentioned countries is extremely important.

\section{Tax Court System of the United States of America and the rule of dispute discussion}

The tax court of the USA is a public body (the so-called 'Court of Record' - a formulation that indicates that each court process is public and, therefore, the information is publicised), which is established by the congress vide Article I of the US Constitution. More specifically, Section 8 indictates that 'the Congress has the authority to define and collect the fees, tax liabilities, payments, and taxes, which are calculated in accordance with the volume of business and not the revenue received from property or real estate, pay the debts, provide general security and public prosperity'. Besides, all tax liabilities should be uniform in the entire United States. The Congress is authorized to constitute tribunals inferior to the Supreme Court (U.S. Constitution, Rules of Practice \& Procedure - United States Tax Court).

Many cases in the tax courts are disputes regarding the federal income tax and fines. In most cases, this happens when the internal revenue service (IRS) carries out control of the taxpayer. After sending a whole range of preliminary written notifications, when a disagreement arises between the taxpayer and the IRS, the latter defines the volume of 'deficit amount' (reduced tax) and publishes a formal notification called 'statutory notice of deficiency' or 'a 90-day letter'. In this context, the term 'deficit' is a legal one and the IRS is not obliged to state the exact amount of the unpaid taxes. After the notification of deficit is issued, the taxpayer has 90 days to appeal against this decision to require a renewed calculation of the 'deficit'. If the taxpayer fails to file the petition in the given timeframe, the IRS is authroised to reflect the mentioned 'deficit' amount in the books of the US Treasury Department. After this, the right of mortgage can be used on the taxpayer (http://www.ustaxcourt.gov/).

The taxpayer is authorized to appeal against this action of the tax body about defining the 'damage' of in various bodies. In this respect, it needs to be mentioned that the tax court is the only specialized institution where the legitimacy of imposing the taxes may be challenged by the taxpayer before accrual (payment) of taxes by the internal 
revenue service. The tax payer is authorised to appeal against issues regarding the accrued taxes by various legislative means (except bankruptcy) but the tax tribunal is the only institution where the taxpayer has the right to question the legitimacy of tax accrual without full payment of the disputed tax amount. The party, which appeals against the imposition of tax can file a suit in any regional court of the United States or the Court of Federal Appeals/Complaints. However, in case of appeal in either court, it is obligatory to pay the tax before filing the suit ("The rule of full payment" established by the precedent in Flora vs. the United States).

Therefore, the tax court is the court forum where the taxpayer can dispute the tax law violations detected by the commissioner of the IRS before paying in full the disputed tax amount. The tax court is authorized to discuss the issue related to the taxation of the taxpayers, including tax disputes and that includes notification regarding the reduction of taxes; warnings sent to the autorised persons; treatment of rehabilitation cases and correcting the issues of cooperation, such as, 'readjustment and adjustment of partnership items'; 'tax disputes concerning notices of deficiency'; 'notices of transferee liability'; 'review of the failure to abate interest'; 'administrative costs'; "Worker classification', 'relief from joint and several liability on a joint return', 'legitimacy of the rewards granted to whistleblowers'; 'review of certain collection actions'.

The court is also authorised to make decisions of declarative (explanatory) nature (declaratory judgment). Such a decision is made in a civil case and is legally binding but does not specifically oblige the parties to act because it belongs to the form of 'preventive review'. Mostly, declarative decisions are used in cases when one party has 'theatened' another by filing a suit in a court but has not yet carried out the threat. Declaratory decisions are authorized by legislative acts, mostly, in the countries that have a common law jurisdiction. In the USA, the federal authority and majority of states in the 1920s and 30s adopted legislative acts that allowed courts to publish decisions of declarative nature.

The taxpayer can request discussion of the case by the court according to 'the procedure defined for small tax cases' for the disputed tax amount that does not exceed US\$ 50,000. During this procedure, the court discusses the case to review it in an accelerated manner. However, the court's decision is not subject to appeal and cannot be used as a precedent. Court processes are carried out by one judge, without a jury and the taxpayer has the right to express his/her interests while discussing the case. The majority of cases are finalised through agreements between the parties without the court process.

\section{Principles of governing the functining of the Danish tax tribunal and the procedure of discussing the dispute in the tax tribunal}

In contrast with countries that have tax courts of justice as an independent part of the justice system, tax and customs issues in Denmark are discussed by the tax tribunal. The concept of the tax tribunal was introduced in 1938 and the tax tribunal is the supreme administrative body that reviews the tax disputes, customs, and property evaluation based on legislation. The tax tribunal is independent of both tax authorities and the Ministry of Finance. Although the tax tribunal is not a court in its classic sense, it has some of the characteristics of the court of law (Rules of Procedure of the National Tax Tribunal, 2005). In Georgia, the discussion of disputes in the tax tribunal and its procedure are mainly regulated by the procedural code of the tax tribunal of Georgia, whereas Danish legislation regulates several issues. Decisions of the national board on property assessment, the tax 
authority, and the board for tax appeals can be appealed against in the tax tribunal. Annually, the Danish tax tribunal reviews approximately 4000 tax and customs disputes and 500 cases on the issues related to property assessment. The tax tribunal consists of seven offices. These discuss the issues within their competence. The first office - taxation of employees, that is, issues related to tax on pensions; issues related to real estate and double taxation. The second office - taxation of corporations and founders/partners, foundations and associations; tax on the income received by capital sale; issues related to the registration and reorganisation of legal entities. The third office - business tax, including, the issues of expenses related to business and manufactured products/services rendered; issues related to accounting; issues related with international transactions subject to international control (transfer pricing). The fourth office - financial instruments; interest rates; goodwill and other intangible rights (assets); depreciation of basic means; property tax. The fifth office - reimbursement of taxes. The sixth office - VAT, customs duty and other taxes. The seventh office - assessing the value and depreciation of property.

Immediately upon receiving the suit/complaint, the tax tribunal starts searching for the information regarding the issue from both the taxpayer and the authorities. As a rule, the case is discussed without an oral hearing. However, in case the taxpayer requests, an oral discussion of the case is arranged. The average duration of the discussion of the suit/complaint in the tribunal is 6-12 months. According to the limit of the tax tribunal, the tribunal makes a decision in writing or by voting as a result of discussing the case. Not less than three members of the tribunal should take part in voting. In the event of a member of the tribunal having a different opinion, it should be adduced to the decision. The decision of the tax tribunal can be appealed against in a court in case valid grounds exist. It can be stated based on the above that the system of discussing the tax disputes in Denmark is mainly based on administrative procedures and it is the tax tribunal that discusses the large majority of tax disputes. The existence of certain legal institutions outside of the justice system in the form of the tax tribunal serves as the instrument of handing only exceptional cases (disputes of special importance) by the state to the bodies of tax and customs dispute review and justice, which operates quite effectively in Denmark. As in the German Federal fiscal court, the tax tribunal of Denmark also discusses the cases with the assistance of the officers and the judges in the narrowest line of specialization. this, substantially reduces the probability of an error and/or incorrect interpretation of the law while making a decision (http://www.uk.landsskatteretten.dk/92/).

\section{Structure of the fiscal court of the Federal Republic of Germany and the rule of its organization}

The federal court of Germany is one of the supreme bodies of justice in Germany among the five bodies established by the Constitution of the German Federal Republic and serves as the final instance (besides the criminal law cases related to the mentioned issues) of discussing tax and customs cases. The main function of the German fiscal court is to ensure the legality of the application of the tax law norms and their execution by interpreting the norms of justice. The function of the fiscal court of Germany is not the only interpretation of tax legislation and definition of the terms undefined by the legislation but also developing the legislation by determining its logical meaning and introducing the united precedent practice (Basic Law for the Federal Republic of Germany). 
Since taxpayers, while discussing disputes, frequently question the constitutionality of several norms of tax legislation, examining the issue of the constitutionality of such questioned norms of tax legislation has been established as one of the main functions of the federal fiscal court in Germany. If such a contradiction with the Constitution is detected, the court is obliged to stop discussing the matter and request the federal constitutional court to decide the issue of the constitutionality of the norm (Tax Court Regulations).

Justice is carried out in Germany by the federal constitutional court, federal courts. and the courts of lands. The following five high instance courts are functioning in Germany, the federal court (for civil and criminal cases), federal administrative court, federal fiscal court, federal labor court, and federal social court (The Fiscal Code of Germany). Unlike the other bodies of justice, fiscal justice is characterized by a twoinstance structure. The courts of the first instance are "lands" fiscal courts. The appellate court serves as the federal fiscal court, which is the court of final instance on the issues of tax and customs (http://www.bundesfinanzhof.de/). Administrative acts that the tax bodies enforce are mainly appealed against in fiscal courts. Court decisions regarding them will be taken into consideration by the respective administrative bodies (tax and customs bodies). Submission of the suit by a taxpayer to the fiscal court is possible only after the taxpayer has used the right to appeal to the administrative body. An appeal against the decision of the fiscal court can be filed in the federal fiscal court.

Currently, 18 fiscal courts with about 600 judges are operating in the Federal Republic of Germany. The cases in the fiscal courts are reviewed by senates consisting of three judges and two honorary judges. The honorary judges participate only in the oral discussions and do not take part in the decision-making. The cases, which are not related to special legislative difficulties and do not have fundamental character may be reviewed by a single judge (http://www.bundesfinanzhof.de/). Currently, approximately, 70000 cases are pending to be discussed in German fiscal courts. Annually, 50000 - 60000 new cases on average are submitted to the courts and decisions given in about the same number of cases. About 4\%-5\% of decisions made by fiscal courts are appealed against in the federal fiscal court.

\section{The procedure of case review in the federal fiscal court}

On the basis of suits (appeals)the federal fiscal court discusses the issue of compliance of fiscal court decisions with federal legislation whereas in special cases, it reviews the issue of compliance with the legislation of "Lands". The federal fiscal court of Germany, as well as the supreme court of Georgia, reviews the decision of the first instance court within the scope of legislative circumstances and does not study new factual circumstances related with the dispute. In case the federal fiscal court considers that the first instance court failed to respectively study the actual circumstances of the issue to be discussed, it returns the case to the fiscal court for a repeated review. The federal fiscal court discusses the cases by an oral hearing. However, due to the overload of cases, in case the parties agree, cases are discussed even without an oral hearing. The average duration of case discussion in the fiscal court is 11 months (http://www.bundesfinanzhof.de/).

The fiscal court of Germany is the most significant and undoubtedly efficient institution in the issues of tax and customs. The existence of the fiscal court enables the 
federal republic of Germany to not only specialise in justice in respect of tax and customs legislation but also establishes senates within this court, which are specialized by even narrower specialization. As for the senates, they discuss tax customs disputes. Besides, each one does it within its own area of competence - one senate discusses only customs issues, two of them - VAT, one part - only the issues related to income tax, etc. Such division of activities to be discussed ensures narrow specialization of judges and, as a result, a substantial enhancement of quality of dispute discussion in court. The German system of justice takes into account one basic interest of the taxpayer in relation to tax and customs disputes and sets up only a two-stage system of discussing the case in court. Overall, the specialized body of justice, judges having specialized and in-depth knowledge and practice around the issue to be discussed, only two instances of court review, serve as the guarantee of exercising efficient and fast justice for both the taxpayer and the state. This, in its turn, supports their activities and creates the mechanism for just execution of tax legislation.

\section{Comparative analysis of discussing the tax dispute in courts}

As stated earlier, the tax dispute is discussed in court with special care. The rules that countries have for regulating the discussions of disputes in their judicial systems are based on the importance they place on the tax disputes. In several countries including, Georgia, tax disputes are discussed by common courts through administrative judicial procedures. In such cases, the judge is allocated tax cases for review together with numerous cases of administrative category. Since administrative law consists of numerous laws and rules, the judge cannot possess in-depth knowledge of all the details and peculiarities of administrative law. Besides, analysis of the number of administrative cases and the volume of tax disputes in them (4\%-6 \% in city courts and $7 \%-17 \%$ in appellate courts) illustrates that the want of enough opportunity for the judges to accumulate sufficient practical experience in deciding tax disputes. It is due to this very fact that several countries established special courts to discuss tax and customs disputes specifically. By this means, the judges gain the knowledge of a specific field and the efficiency of discussion and settlement of tax dispute increases substantially and the probability of an error in judgement decreases significantly. It facilitates the introduction of proper court practices that bring clarity to ambiguous or unclear norms in legislation and lead to a unified approach to the resolution of disputes. Based on the foregoing, it is concluded that the existence of specialised tax law tribunals and courts will significantly improve the efficiency of the delivery of justice in this area of law and establish a unified approach to the issues addressed by tax legislation in the country.

\section{Importance and Structure of Introducing Tax Court}

Statistical information on the discussions of administrative (including tax) disputes in common courts of Georgia clearly illustrates that due to the small number of tax disputes the court handle, there is little possibility of enhancing the theoretical or practical knowledge in this field of law. This situation affects the quality of discussion of tax disputes and increases the probability of mistakes being made by the court while deciding a dispute (in actually deciding the issue and verifying the decision). 
In case tax courts are established in Georgia, the degree of trust of taxpayers in the institution of court in Georgia will rise significantly develop. The length of discussion on cases will decrease, which will benefit both taxpayers and the state (tax bodies), the institution will be created which will establish in the country proper court practice, the decisions will be logically and legally sound, which may decrease the number of appeals against such decisions. Besides, independence will rise and the trust of the public in the courts will increase. Taking into consideration the structure of the courts in Georgia and statistical data of their activities, it is possible to suggest the following reforms concerning specialisation in tax dispute review:

- Tax disputes should be separated from the chamber of administrative affairs in appellate courts and the tax affairs chamber should be established for discussing and deciding the disputes in the category of tax and customs.

- This will lead to the development of specialised knowledge of the relevant laws and of discussing the cases of the tax category in the chamber of tax affairs with a specialized board within the system of general courts. In such a case, tax disputes will be discussed by the specialized board and a two-instance structure (appellate court and supreme court) for discussing the tax dispute will be created without establishing an independent tax court.

- The establishment of the proposed structure will improve the quality of discussion of tax disputes and (though, possibly, not as much as in the case of independent tax court as in other countries). It will lead to the establishment of court practices in the sphere of tax law. raise the qualification of judges in the specific area of tax law by accumulation experience. This, along with the establishment of court practices will accelerate the discussion, decision, and dispute review. Without Constitutional changes and independent of the state legislative authorities, it is impossible to establish the institution as a legal entity of public law for discussing tax disputes in the manner of the law courts.

With the view of organizing the process of dispute review, it should be defined at the legislative level that tax disputes are discussed in the system of the ministry of finance and LEPL "Bureau of Discussing Tax Disputes". It is advisable to establish at the Bureau of Tax Dispute Review several chambers whose competence will be defined according to the specific issues in the tax disputes (for example, the first collegium - customs disputes, second collegium - indirect taxes, third collegiums - direct taxes, etc.) whereas dispute review and discussion should be carried out in a collegiate manner - with three arbiters. Taking into consideration the importance of the object of the dispute and the sum of money in dispute, in case the taxpayer demands, it should be possible for the arbiter to individually discuss the dispute for an accelerated dispute resolution, and at the same time clarify that the decisions made in such cases will not be subject to appeal.

Besides, together with the establishment of the review institution, much importance should be given to the systematic publication of decisions on tax disputes without identifying the taxpayers involved. This will give the taxpayers access to the practice of execution of the norms of tax legislation, which will reduce the cases of errors made because of the incorrect understanding of the law or a specific norm by the taxpayer.

The suggested reforms will make it possible to establish an independent body for discussing tax disputes. Decisions made by this body will be revised/controlled by the 
Supreme Court and this will ensure a most detailed and competent review of tax disputes leading to the establishment of the united practice in this sphere.

\section{Conclusion}

By the introduction of the institution of tax courts/tribunals in Georgia, the condition of tax bodies and taxpayers will significantly improve in Georgia:

- Tax courts/tribunals should be established.

- Disputes should be discussed by the judges possessing special knowledge and experience and the taken decision will in most cases be comprehensively justified. this will convince the disputing parties that the decisions are just and legitimate and in several cases, this will save the expense of time and money for the parties on needless appeals in the higher instance.

- The tax court/tribunal judges should meet the following requirements. They should not be less than 30 in number, should have the valid qualification to hold the position of a judge and possess special/specific knowledge of tax and customs law.

- Tax disputes should be discussed in the two-instance structure of the tax court/tribunal.

- A 3-month limit should be set for discussing each tax dispute in each instance of the tax court or tribunal to ensure timely resolution of the issues, which is equally important for both taxpayer and the tax authority.

Court practice on tax issues should be introduced and generalized to define inaccuracies in tax legislation and eliminate unregulated issues. This will reduce the instances of imposition of taxes based on an incorrect interpretation of the law by the tax authority and incorrect understanding of the law by taxpayers.

\section{References}

1. Administrative Procedural Code of Georgia., 2018. Tbilisi. LEPL of the Parliament of Georgia. “Legislative Messenger”, Codified. Available at www.matsne.gov.ge.

2. Basic Law for the Federal Republic of Germany. Available at, http://www.bundesfinanzhof.de/

3. Cernius, G., Birskyte, L., \& Balkevicius, A. (2016). Influence of rules for computing corporate income tax on the accuracy of financial statements of Lithuanian companies. Analele stiintifice ale Universitatii “Al. I. Cuza” din Iasi. Stiinte economice/Scientific Annals of the" Al. I. Cuza". Vol.63, no.1, 65-81, DOI: http://dx.doi.org/10.2478/aicue-2016-0005

4. Civil Procedural Code of Georgia. 2018. Tbilisi. LEPL of the Parliament of Georgia. "Legislative Messenger”. Codified. Available at www. matsne.gov.ge.

5. Chalmers D., Davies G., Monti G. European Union Law: Cases and Materials. 2nd Edn. Cambridge University Press. 26 July 2010.

6. $\quad$ Craig P., De Búrca G., The Evolution of EU Law, Oxford University Press, 2011;

7. Constitution of Georgia. 2018. Tbilisi. LEPL of the Parliament of Georgia. "Legislative Messenger". Codified. Available at www. matsne.gov.ge.

8. $\quad$ Efficient institutions of tax dispute resolution. USAID, February 20, 2012.

9. Gorbunova, O.N. (ed.) Financial Law. Moscow, 1996.

10. Finanzgerichtsordnung.

11. General Administrative Code of Georgia. 2018. Tbilisi. LEPL of the Parliament of Georgia. “Legislative Messenger”. Codified. Available at www. matsne.gov.ge.

12. Kerzel, M. Judicial Review within Danish Tax Law. 
13. Kemularia R. 2014. The system of tax disputes of Georgia. Articles/Business and Economy, 06 March 2014.

14. Korkelia K. 2002. The Role of the Case Law of the European Law of Human Rights in Practice of Courts of Georgia. Tbilisi.

15. Lupu, D., Maha, L. G., \& Viorică, E. D. (2020). COVID-19 Incidence in Europe: Drivers and Government Interventions. Transylvanian Review of Administrative Sciences, 16(SI), 80-93, http://dx.doi.org/10.24193/tras.SI2020.5

16. Liluashvili T. 1999. Administration of Civil Cases in Court. Tbilisi.

17. Parshkov A.N. The Procedure of Tax Dispute Resolution in the USA /A. N. Parshkov//URL: https://www.sovremennoepravo.ru/m/articles/view/ 2014-01-04 (Date of downloading: 06.12.2016)

18. Pertova G.V. 2004. Types of Tax Disputes in Court Practice and Trends of Developing Legal Regulation of Tax Relations. Financial Law, 2004. № 2;

19. Rules of Procedure of the National Tax Tribunal (Forretningsorden for Landsskatteretten (BEK nr.974 af 17. October 2005)

20. Rusiashvili J, Tabutsadze I, 2000. Comments to the Administrative Procedural Code of Georgia. Tbilisi.

21. Semushkin V.S. Preliminary Tax-Jurisdiction: Problems and Prospects//Tax Disputes: theory and practice. 2005. № 6. C. 39-43; № 7 .

22. Tax Code of Georgia, 2018. Tbilisi. LEPL of the Parliament of Georgia. "Legislative Messenger". Codified. Available at www. matsne.gov.ge.

23. The Fiscal Code of Germany.

24. U.S Constitution, Rules of Practice \& Procedure - United States Tax Court. Available at http://www.ustaxcourt.gov/

25. http://en.wikiquote.org/wiki/Benjamin_Franklinix. [24.09.2012]. F

26. http://www.supremecourt.ge/statistics/

27. http://www.uk.landsskatteretten.dk/92/

28. http://www.bundesfinanzhof.de/

29. Internet course. mof.ge; rs.ge; Supremecourt.ge; tcc.gov.ge;

30. Web site of the Board of Dispute Review of the Ministry of Finance of Georgia. Tbilisi. www.taxdisputes.gov.ge.

31. Timer.ge, January 9, 2018

32. http://www.ustaxcourt.gov/

33. http://smallbusiness.chron.com/tax-advantages-nonprofit-10551.html

34. http://smallbusiness.chron.com/tax-law-nonprofit-organization-63880.html

35. http://www.investopedia.com/ask/answers/08/nonprofit-tax.asp

36. http://www.twobirds.com/en/news/articles/2014/global/tax/oct-14/germany-and-tax-exemptionrules-for-nonprofit-entities

37. http://www.twobirds.com/en/news/articles/2014/global/tax/oct-14/francetax-incentives-of-nonprofit-organisations 